\title{
КАЛЕНДАРСКО ЗНАЊЕ И АГРАРНИ КАЛЕНДАР У СРПСКИМ ОБРЕДНИМ ПЕСМАМА
}

Прелазак на земљорадњу као главни вид привређивања захтевао је усавршавање у начину традиционалног рачунања времена. Стога, лунарни календар замењен је соларним, у ком су периоди године (летње и зимско полугође) одређивани на основу четирију кључних положаја Сунца - краткодневице (зимски солстицијум), двеју равнодневица и летње дугодневице. Ови тренуци годишњег циклуса христијанизовани су и везани за одређене хришћанске светитеље, чије је светковање уједно означавало и след пољских радова. Посматране песме прате све сегменте јавног живота, од зимских обреда (коледари), у којима доминирају магијске радње везане за раст семена (уз игру, коледари припевају: иуn, иуп, коледо, оволико жито да родu), преко песама пролећног круга, којима се изричу аграрни благослови и изводе магијске радње којима се „затвара зима” и „отвара лето”, упоредо са пролећним радовима. Животни циклус семена, отпочет орањем и сетвом, завршава се жетвом, као колективним, радосним чином (моба). Ове песме чувају траг древног веровања да човеку корист може донети само рад који је обављен како треба, уз поштовање времена за рад, одн. табу прописа за дане током којих се рад избегава.

Кључне речи: обредне песме, фолклорна темпорологија, аграрни календар, соларни календар, мит, традиција, мушки послови, земљорадња, цикличка обнова.

Живот традиционалног човека најнепосредније је зависио од природе - смене годишњих доба, повољних атмосферских прилика или непогода. Саживљен с природом, он је изградио осећај за след њених промена, а свој рад ускладио с ритмом цикличких понављања. Када му временске прилике не би ишле наруку, он би магијским путем (првенствено хомеопатском и магијом додира) настојао да изазове промену стања - додолским и крстоношким

\footnotetext{
*dragoljub.peric@ff.uns.ac.rs

** Део истраживања у оквиру овог рада представљен је на научном скупу „Теорија и пракса аграра у историјској перспективи” у организацији „Центра за аграрну историју" 16. 11. 2017. на Пољопривредном факултету у Новом Саду.
} 
песмама - падање преко потребне кише, али и - инверзним радњама и песмама - њено заустављање (уколико обиље падавина, у невреме, угрози летину и род воћа и поврћа).

Правилност у смењивању промена у природи, настала периодичним слабљењем и јачањем сунца у митско-магијском систему мишљења традиционалног човека, тумачена је као периодично рађање, снажење и умирање Бога Сунца - божанства које васкрсава природу, вегетацију, регулише плодност стоке, а истовремено магијски стимулише виталитет у колективу преносећи људима животодавну снагу обнове - у потомству, снази и добром здрављу (ложење ватре на Бадњи дан, петровданске и ивањданске лиле и сл.). Отуда се јавља и „потреба да се време потчини циклусима”, што „произилази из понављања природних појава, али и човекове жеље да те појаве уреди" (Аjdačić, 2000: 130).

Како је мистерија периодичног слабљења и јачања сунца имала кључни значај за земљорадњу, аграрни календар захтевао је унапређење у погледу традиционалног рачунања времена. Лунарни календар замењен је соларним, у ком су периоди године (летње и зимско полугође) одређивани на основу четирију кључних положаја Сунца - краткодневице (зимски солстицијум), двеју равнодневица (пролећни и јесењи еквиноциј) и летње дугодневице. Ове тачке годишњег циклуса, уз неке друге празнике, претежно из круга пролећне обредности, као и њихово празновање у периоду многобожачке религије, преслојене су с примањем хришћанства, а дати дани везани су за култ појединих хришћанских светитеља, при чему се иза њихових атрибута и функција и даље запажају древне црте старих паганских божанстава. Њихово обележавање и календарско смењивање уједно је означавало и след пољских радова. Празници посвећени одређеним светитељима (обично - тзв. црвена слова), уз запрешне, ${ }^{1}$ заповедне, варовне (тј. поштоване, а када се не поштују, потенцијално опасне) и усечне дане, ${ }^{2}$ као и уз недељу, представљају сакрално време, тј. дане током којих се не ради (или се избегавају одређене врсте послова), „али се управо празници одређују као међаши за одређене послове. Њима се одређују почетак и крај неке радње" (Исто: 129). На најважније празнике годишњег циклуса извођене су одређене календарске обредне песме, док су други означени у сукцесији смењивања пољских радова, опеваних у песмама.

\footnotetext{
1 Дан означен у црквеном календару крстићем, када се не сме радити.

2 Дан у недељи на који те године пада Усековање главе Св. Јована Крститеља.
} 
Разлике између аграрног и хришћанског календара условљене су првенствено тиме што је земљораднички календар користио елементе лунарног календара, везујући се за њега код послова од нарочитог значаја за заједницу, попут сетве:

Почетак овог посла био је, на пример, усклађен с месечевим менама. У неким крајевима сејало се на уштап, а у неким, сасвим супротно, на младину. Радило се, очигледно, о веровању да својства Месеца неким тајанственим путем прелазе на семе, а преко њега и на будуће усеве. С једне стране, пун месец изазивао је асоцијације на пуне амбаре, ${ }^{3}$ на богату летину. С друге стране, раст месечевог српа асоцирао је на раст усева. (Bandić, 1991: 275)

Међутим, постојала је и другачија пракса. Колебање између лунарног и црквеног календара око одређивања времена сетве огледа се и у томе што су, сем везивања за Месечеве мене, као оријентир за време сетве озимих жита послужили и различити црквени празници - од Св. Симеона Столпника (14. септембар), преко Мале Госпојине (21. септембар), све до иза Томиндана (19. октобар) - у зависности од климатских услова одређене регије (в. Nedeljković, 1990: 203, 145, 240). И поред овако широко постављеног распона празника временских оријентира спрам којих се одређивало време сетве - увид у поетску грађу предочава другачију слику: време сетве, по правилу, не помиње ce.

Могуће разлоге требало би тражити првенствено у значају сетве као култног чина. Како је реч о радњи од прворазредног значаја за читаву заједницу, могуће је да се време сетве намерно табуизира (не помиње) како би се принос заштитио од злих утицаја:

По општераспрострањеном схватању, сетва је била критични, преломни моменат сваког производног процеса, моменат у коме понашање како самих посленика, тако и припадника њихове заједнице непосредно утиче на раст усева, самим тим и на количину и квалитет приноса у текућој години.

Посебна пажња била је посвећена избору времена у коме ће се сетва обавити. Пре свега се водило рачуна о календару православне цркве. Пољски радови - а ту свакако спада и сетва - нису се обављали на дане великих, 'заповедних' празника. (Bandić, 1991: 274)

Низ забрана односио се како на заштиту магијске чистоте семена тако и на самог сејача и његово избегавање контакта с особама које би могле

3 „Жито треба сејати док је месец пун да би класје било пуно и једро.” (Vuković, 1985: 178) 
штетно утицати на род усева (Исто: 276-277). Стога, време сетве житних култура, као и сам чин, у песмама као да се намерно митологизује (онеобичавањем запреге коју чине јелени, као и делова опреме који се користе као апотропајони), ${ }^{4}$ а сетва приказује као сакрални акт - прворадња:

Орач оре равно поље, рало му је чудно дрво, чудно дрво давиново, семе му је ситан јечам, волови су два јелена, два јелена, два анђела, остан му је струк босиљак, брана му је црно перо! (Nikolić, 1966: бр. 6)

Изузетак (у односу на остале житне културе) представља просо (у варијантном кругу песама - и овас), ${ }^{5}$ чије се сејање ограничава до Св. пророка Јелисеја (27. јуна): Јелисије просо сије, иде Виде да обиде, ито је никло нека pacme, а што није нек' не ниче. (Nedeljković, 1990: 110) Будући да се у традицији просо и овас сматрају за култно нечисте биљке 6 и везују за хтонски

\footnotetext{
${ }^{4}$ Поштовање јелена као свете животиње датира још из времена палеолита, тј. везује се за ловачку културу. При преласку на земљорадњу, сачувани су трагови обредне праксе приношења јелена на жртву на крају жетве. Код Јужних Словена јелен носи соларну симболику, а има и карактеристике животиње медијатора (в. SM, 2001: 247248 и др.). Као остан - мотку којом се подбада и тера стока - необични орач користи босиљак - моћни апотропајон против штетних утицаја (С̆ajkanović 4, 1994: 36-43), при чему би помињање босиљка у песми уједно могло бити и одраз обредне праксе приликом сетве, мешали би босиљак са семеном како би семе, а тиме и будући принос, заштитили од штетних утицаја (SM, 2001: 46; Bandić, 1991: 275 и др.). Сличну симболику има и црно перо, које, као део орачеве опреме (сечиво на плугу), сем отклањања штетних утицаја, указује и на лакоћу с којом се дата (прво)радња обавља.

5 У једној песми о Христовом рођењу читава природа одаје почаст Богородици и новорођеном Христу, изузев проса: Сво вој се поље придиже, / Кићано просо не теја - / Од њега се колач не меси, / [И] у иркву се не носи. (Karanović, 1996: бр. 24)

${ }^{6} \mathrm{У}$ божићној песми из околине Лесковца губљење култне чистоте проса тумачи се као огрешење - само јасика (трепетљика) и просо нису поштовали заустављање читаве природе приликом Христовог крштења, те их сустиже казна:

Стаде гора, стаде вода,

[...]

Повија се ов'с жито.
} 
свет, ${ }^{7}$ сетва ових житарица није праћена табу прописима, за разлику од сетве најзначајнијих култура - пшенице и јечма.

Како је аграрни календар повезан с циклусом пољских радова, они су ce, због прецизности, временом везивали за фиксне датуме. Стога, земљораднички календар годину је делио на два полугођа - зимско (од Митровдана до Ђурђевдана) и летње (од Ђурђевдана до Митровдана), следом смењивања радова. Зимско полугође обухвата период престанка аграрних радова (када су ливаде покошене последњи пут, пшеница посејана, а земља припремљена за наредни циклус), ${ }^{8}$ тј. време послова претежно оријентисаних на бригу око стоке и кућне послове - спремање дрва за зиму, припрему вина и печење ракије.

Митровдан (8. 11) означава почетак зимске половине године. Активности везане за овај дан углавном означавају крај пољских радова, везаних за претходно полугође: „О Митрову дне исплаћују се најамници, плаћају дугови и сл. У многим крајевима домаћинства која су држала слуге, узимали су их на Ђурђевдан, а исплаћивали на Митровдан.” (Nedeljković, 1990: 155) Свест о томе да овај дан означава крај пољских радова рефлектована је у песми: Митровдан поље свршено / увати гъездо те седи. (Bovan, 1977: 70) Симболика граничног времена спаја у себи представе о суштинској истоветности почетка и краја у митском (цикличном) концепту времена. Док у овим стиховима Митровдан означава крај радова на њиви, у централној Босни Митровдан је време њиховог симболичког почетка: „У

А ти жито, ов'с жито,

У колач се не месило,

У цркву се не носило! (Đorđević, 1990: бр. 17)

В. и: Karanović, 1996: бр. 26.

${ }^{7}$ Да не би чињарице обрале млеко стоке или да им не би вештице нашкодиле, сељаци су посипали просо око торова и штала, уз речи: „кад ... покупе просо, онда да вам узму варенику" (С̆ajkanović 4, 1994: 167), тј. када вештице преброје зрна проса, онда да дођу (Исто; SM, 2001: 453).

8 „У прошлом веку [мисли се на XIX в. - Д. П.] су у Шумадији од Крстовдана укомуњивали ливаде тј. пуштали стоку у слободну пашу по пољу, а чобани су се окупљали на игру у пољу. Тамо где је било сеоских пољака, њихова дужност је престајала о Крстовдану, па су их, као у Црној Гори и Санџаку, тога дана домаћини исплаћивали за чување усева од штете.” (Nedeljković, 1990: 126) 
Височкој нахији су веровали да на Митровдан ваља убраздити њиву која ће се засејати пшеницом" (Nedeljković, 1990: 155). ${ }^{9}$

Веза сетве с представама о оплодњи земље, односно представама о смрти као обнављању и васкрсењу, рефлектована је, на симболичком нивоу, на поједине ритуале зимскога циклуса (првенствено божићне), обредне реквизите (варица, божићњак), а потом и на песме - вербални део обреда. Код Словена за сетву су се користила зрна из венца од жита, последњег снопа или „божје браде” - последњег пожњевеног свежња жита са њиве, у коме је, верује се, магијски концентрисана плодоносна снага жита (Njevjadomski, 2000: 40-42; SM, 2001: 47; Čajkanović 4, 1994: 171). Како су за традиционалног човека сетва и жетва нераскидиво повезане и представљају почетак и крај истог циклуса, односно јединство супротности, „жетва означава крај 'старог' стадијума вегетације и постепени прелазак на 'нови"” (Njevjadomski, 2000: 41), тако да коришћење за сетву зрна жита из жетвеног венца, освећеног у цркви, код Пољака (Исто: 42), односно из класова „божје браде” код Источних и Западних Словена (SM, 2001: 47) и Срба (Čajkanović 4, 1994: 171), као вид обредне праксе, јасно указује на то да међусобно прожимање сетве и жетве, на овај начин, одражава идеју о континуитету животног циклуса семена, а самим тим и континуитету живота.

Разлике између аграрног и хришћанског календара смањују се, а они узајамно надопуњују за време новогодишњих празника, који, семантиком суседних датума (Бадњи дан и Божић), најпластичније изражавају симболичка значења краја и почетка циклуса, транспонованих на план животног циклуса семена. У ширем словенском контексту посматрано: „сељаци из Комаровича у мозировском округу додавали су семену за жетву зрна из класова који су стајали у кући за време бадње вечери [...] Домаћини из борисовског округа тражили су међу сеном и сламом за који су за бадње вече стављани на сто зрнца која су затим додавали семену за сетву.” (Njevjadomski, 2000: 43) Код Срба пшеницом се посипа бадњак (Čajkanović 4, 1994: 170), а на полажајника, чим ступи у кућу изјутра на Божић (7. јануара), домаћица баца

\footnotetext{
${ }^{9}$ Интернационална симболика прворадње као понављања и обредне реактуелизације одређене радње која постаје предмет култа одражена је и у наведеном веровању: „Раширена, и свим народима позната, симболика прве бразде, првог семена, првог класа или плода и др., у земљорадничком календару показује се у започињању одређених радњи у дане који су утврђени одређеним памћењем, а изводе се тачно у одређени дан или у периоду везаном за одређени празник” (Аjdačić, 2000: 127).
} 
жито, желећи тиме магијски да призове плодност усева и стоке, као и свеопшти берићет током предстојеће године (Grbić, 1909: 90). Пшеница је видно место имала и на божићној трпези, као неизоставни део варице култног јела сачињеног од смеше различитих семена, својеврсне жртве у семену (панспермије - уп. Čajkanović 4, 1994: 169), ${ }^{10}$ али и симболички репрезентована на божићном хлебу (чесници, божићњаку), где су биле различите фигуре од теста, међу којима доминирају оне везане за аграрни тип културе (њива, ујармљени волови, снопови жита положени унакрст, грозд, птица, слово и сл.). ${ }^{11}$

За овај (по мишљењу неких етнолога - најзначајнији) празник годишњег циклуса везују се коледарске и божићне песме. Извођене су од Св. Игњатија (2. јануар) до Богојављења (19. јануар), а најчешће за Бадње вече и Божић (в. Karanović, 1996: 260). Зимска краткодневица светкована је као завршетак старе године и повратак Сунца са северног повратника, при чему је „у свести примитивног човека та појава у природи замишљена [...] као рађање младог сунца, које ће да пробуди природу из зимског мртвила и да је оплоди" (Latković, 1991: 154). Бадњи дан је тако у нашој традицији представљао последњи дан старога циклуса (старе године) и ритуално је супституисан бадњаком, чије ложење репрезентује „Старога” - божанство које умире, док Божић оличава почетак новога циклуса, тј. рођење „Младога” Бога. ${ }^{12}$ Организоване поворке колеђана, бројне магијске радње које они изводе, ${ }^{13}$ као и коледарске песме, као особите магијске формуле, имале су за циљ да потпомогну правилно затварање старог и отпочињање новог циклуса и да обезбеде плодност и благостање у предстојећој години.

${ }^{10}$ Више о варици у: Bandić, 1991: 304. Припрему и конзумацију варице пратиле су песме попут:

Вар-варица вари (Света великомученица Варвара), Сав-савица лади (Свети Сава Освећени),

А Никола куса (Свети чудотворац Никола). (Vrčević, 1883: 15)

11 Тако изгледа божићни колач који се и даље меси у околини Смедерева уочи Божића - Д. П.

12 Вук Стеф. Караџић, у коментару уз песму бр. 190 (Karadžić, 1988: 144) каже: „Овде се бадњак спомиње као некакав човјек или бог (као и Божић)" (истакао В. С. К.).

13 Примера ради, ритуални плес, праћен речима песме: Цуn, коледо, / Цуn, коледо, / Оволико жито да роди (Đorđević, 1990: бр. 14), имао је за циљ да магијски подстакне висок раст (и принос) жита. 
Тако су два суседна празника - Бадњи дан и Божић - интегрисали у себе две хипостазе бога природе, који периодично умире и васкрсава. Време старог циклуса хаба се, прља и троши. Да би се нови циклус успоставио, стари мора бити поништен, што укључује магијски симболизам различитих обредних радњи (Elijade, 1986: 94), најзад и - спаљивање бадњака. С обзиром на лиминални карактер ових празника, гатало се тада о летини у предстојећој години (в. Грбић, 1909: 88), а магијском снагом благослова настојао се призвати добар приплод стоке и род усева (уп. Karadžić, 1898: бр. 183). ${ }^{14}$ Магијска делотворност речи функционише тако што песма слика богатство и обиље које се прижељкује тако као да се оно већ остварило, призивајући тиме, имитативном магијом, богату летину и догодине (в. Zlatanović, 1982: бр. 5). ${ }^{15}$

Божанство сунца (Сварогов син Дажбог - SM, 2001: 485) и вегетације, као и свеколике плодности у природи, у тору и на њиви у низу коледарских песама приказано је као новорођенче у седлу, ${ }^{16}$ на враном коњу, које доноси ветар (Zečević, 2008: 106-109). ${ }^{17}$ Негови атрибути су: вранац, зелени бор, пшеница, винова лоза... Стога, Зечевић закључује да је „дете из наших коледарских песама сунце, тј. божанство сунца [...] На почетку нове Сунчеве године, исто као и на почетку новог животног циклуса људи, за време зимског солстицијума, када сунце почиње да јача, соларно божанство се рађа, дете је” (Исто: 111).

Његово рођење обзнањује пчела (уп. Grbić, 1909: 94), а постепено снажење усклађено је с аграрним циклусом пролећних радова: од сетве јарих усева, преко првог брања плодова раног воћа, односно првог напасања стоке и муже, које су, на обредној равни, пратиле пролећне обредне песме: лазаричке, ускршње, Ђурђевске и спасовске песме, као и њима својствене магијске радње.

Лазаричке песме извођене су током Цветне недеље (недељу дана пред Ускрс), а понајвише на Лазарев петак, тј. суботу, односно на празник Цвети,

${ }^{14}$ В. сличне аграрне благослове и у: Karadžić, 1898: бр. 180-182, 185, 186, 205; Jovanović, 1922: 32-33 и др.

${ }^{15}$ Сличан благослов доброг рода приказан је и у лазаричкој песми (в. Đorđević, 1990: бр. 105).

${ }^{16}$ Идентично се Млади Бог приказује и у лазаричкој песми: Подуна ми тијан ветар, доз, доз, / Издува ми врана коња, доз, доз, / И на коња свил'но седло, доз, доз, / И на седло мушко дете, доз, доз, / И на дете ирвен фесић. (Đorđević, 1990: бр. 42)

${ }^{17}$ Уп. следеће стихове: Ветар веје, Коледо, / Са планине, Коледо, / Те довеја, Коледо, / Врана коња, Коледо, / И на коњу, Коледо, / Бојно седло, Коледо, / И на седлу, Коледо, / Мушко чедо, Коледо [...] (Stanojević, 1929: бр. 52). 
претежно у источној и јужној Србији. Изводила их је поворка лазарица девојака обучених у беле кошуље и искићених цвећем. Кићење учесница, као и биљна и акватичка симболика песама, повезује их с култом плодности и магијском моћи раста биља и вегетације, а синкретичност обреда, који укључује ситно цупкање, симболика васкрсења природе и обнове (присутна у њиховим песмама), те припев - ладо - с елементима аграрне магије, тј. магијског стимулисања плодности усева (Zečević, 2008: 125). Паралелизам у кретању поворке лазарица и кишног облака (Облак, облак над село [...] Наш је лазар над село - Đorđević, 1990: бр. 30), аналоган паралелизму између обредне поворке на земљи и атмосферских прилика у додолским песмама, ${ }^{18}$ упућује на њихову моћ над падавинама. ${ }^{19}$ Богат род који оне призивају на кућу у којој их лепо дочекају открива њихову везу с култом плодности, те неки фолклористи лазаричку опходњу виде као обред земљорадника (уп. Bovan, 1977: 84-85):

Родило се, преродило,

Тегом земљу натежало,

На орача досадило,

На волови додејало,

На амбари натежало. (Đorđević, 1990: бр. 31)

Пчела се, лајтмотивски, појављује у пролећним обредним песмама као весник родне и богате године. Аналогно традицији словенских народа, пчела представља божје створење са симболиком чистоте, светости, склада, слоге, али и богатства, бројности, обиља (уп. SM, 2001: 458-460). ${ }^{20}$ Она у ускршњој песми најављује богато лето:

\footnotetext{
${ }^{18}$ УП. Karadžić, 1988: бр. 187, 188 и др.

19 Као што могу својим благословом да призову кишу и тиме повољно утичу на плодност усева, лазарице, уколико се укућани огреше о њих, могу и да „,распоју' (пониште) такве жеље” (Zečević, 2008: 117), чиме се читаво домаћинство излаже штетним дејствима оностраних сила.

${ }^{20}$ Веза пчела са култом плодности у српској традицији, изведена из њихове бројности (повезивањем са пахуљама, капима кише, зрнима пшенице и сл. - уп. SM, 2001: 459), допринела је томе што се магијским радњама са пчелама подстицала плодност у лазаричкој песми: Зададе се таман облак. / Неје облак но су пчеле. / На ножииу по ложииу, На главииу каленицу. / Да благсовем, зададе се, / Зададе се таман облак (Pešikan Ljuštanović, 2012: бр. 77). Радње којима се антиципира плодност стоке укључују пчеле, понекад и мраве, а изводе се понајвише на Божић (Nedeljković, 1990: 42) и Ђурђевдан (Исто: 73) - граничне моменте новог циклуса.
} 
Долете челка од Бога,

Казује лето богато:

Великдан шарен, прешарен,

Ђурђевдан травком и шумом,

Петровдан белим јечменом. (Jastrebov, 1886: бр. 119)

Млађа и потпунија варијанта ове песме поред типске семантике благослова плодности преноси и аграрно знање о следу пољских радова, а сугестијом благовременог доспевања усева призива плодну аграрну годину:

Долете челка од Бога,

казује лето богато,

Велигдан белом променом,

Ђурђевдан белом јагањцем,

Никољдан травом зеленом,

Спасовдан житом класаном,

Петровдан српом и косом,

Крстовдан гувно спраљено,

Митровдан поље свршено,

увати гњездо те седи. (Bovan, 1977: 70)21

Само рад обављен кад треба и како треба - уз поштовање система веровања и забрана везаних за одређене дане и одређене радње - донеће добробит. Стога је след пролећних радова у заједници усклађен с пролећним кругом празника (Ускрс, Ђурђевдан, Спасовдан, Млади Св. Никола) и табу прописима скопчаним уз њих. Како имају сакрални карактер, на те празнике није се радило, али су подузимане разне заштитне радње (против града, грома, штеточина и сл.), као и различита гатања за успех летине, односно магијске радње које су имале за циљ повећање приноса.

Међу празницима пролећног циклуса нарочито је значајан Ђурђевдан. Од Ђурђевдана се рачуна летња половина године, што указује на лиминални карактер празника. У српској традицији Ђурђевдан је важан празник и „главна сточарска светковина" (Nedeljković, 1990: 72), те се наклоност божанства вегетације (које супституише Зелени Ђурађ/Јурај) и стоке настоји стећи приношењем жртве - ђурђевског јагњета. Често се у ђурђевданским ритуалима преплићу елементи аграрне и сточарске магије, тако да их је понекад тешко разлучити. Добар род житарица магијски антиципира плодност стоке, а истовремено штити стоку од штетних утицаја. У Алексиначком

${ }^{21}$ В. и ђурђевску варијанту ове песме у: Karanović, 1996: бр. 97. 
Поморављу тада се обилазила стока, а око обора магијски исписивао круг од зрневља ,да се стока пати као зрно у класту” (Исто: 74).

Ослобађање воде и снага природе представљено је у ђурђевским песмама доласком младог коњаника (Зеленог Ђурђа), који разбија девет педа леда и том водом запаја „лењиве девојке” и „младу момчадију”, преносећи на њих снагу и моћи природе (в. Bovan, 1977: 57). Он кити девојке и момке зеленилом, доноси плодност на њиву, хиперболичан раст биљака. Стога, њему припада симболизам вегетације, а од обредних радњи уочи празника и на тај дан широко је распрострањено плетење цветних венаца, првенствено од здравца, млечике и разног цвећа, чиме се магијски стимулише здравље и млечност стоке (в. Čajkanović 4, 1994: 86, 150; Nedeljković, 1990: 75) ${ }^{22}$ и др.

Од Ђурђевдана се рачуна летње полугође, тако да симболизам прворадњи - обредних радњи којима отпочињу свакодневни послови попут муже оваца, припреме сира, првог клања јагњади и сл. - доминира. С обзиром на семантику овог празника, сетва неких култура, попут кукуруза, везује се за Ђурђевдан као време почетка. Тип климе такође утиче на календарско фиксирање неких послова. „У Лесковачкој Морави [...] 'углавном сви земљорадници се управљају према Ђурђевдану, али се он сади све до летњег Светог Николе”" (Ајdačić, 2000: 127), тј. до 22. маја. Међутим, „у сарајевској котлини: 'кукурузи се највише сију у јечмину, обично на 10 дана пред Ђурђев-дан и 15 дана по Ђурђеву-дне. Најљепша је сјетва по Ђурђеву-дне, а сију се и треће недјеље"” (Исто: 127), а у топлијим крајевима (Зета, Црмница, Бар, Улцињ) сетва касног кукуруза протеже се све до Видовдана (Исто). Наравно, на сам Ђурђевдан се не ради, а „у Левчу и Темнићу [...] на три дана пред Ђурђевдан није сејан кукуруз јер ће да га поједе много црв” (Nedeljković, 1990: 79). Како се сада назире принос житарица, у неким ђурђевским песмама Св. Ђорђе се јавља као покровитељ усева:

- Свети Ђорђо, какво ти је поље?

- Поље ми је лепо и убаво:

Р'жови су два чоевкја боја,

А пченице у клас удариле,

А јечмови већ су забелели. (Đorđević, 1990: бр. 149)

${ }^{22}$ B. Karanović - Pešikan-Ljuštanović, 1994: бp. 40, 41. 
Док Ђурђевдан представља један од најзначајнијих празника сточарских култова, аграрни симболизам, везан за напредовање житарица, припао је празнику из лунарног календара - Спасовдану (прославља се шестог четвртка по Ускрсу). ${ }^{23}$ Иако је сачуваних спасовских песама мало, оне, ипак, испољавају извесне тематске сличности - говоре о обичају плетења венаца, те о надолазећим снагама природе и јачању вегетације, величајући победу сунца, сила раста и снаге светла над силама мрака, хладноће и мртвила зиме. Отуда и неке од песама које се односе на раст житних култура као да представљају варијанте ђурђевских песама о светитељу који обилази поља:

- Свети Спасо, какво ти је поље?

- Моје поље од свем понајбоље:

Све 'шенице у клас укласале,

Све ливаде у цвет уцветале,

Сви ржови у земљу полегли,

Сви јечмови коњу до колена! (Đorđević, 1990: бр. 156)

Свети Спас(а) је типски приказан као коњаник пред којим све озелењује, напредује и расте, што би могло указивати на то да је он заменио паганског младог бога вегетације, преузимајући његов дан као „пролећни празник сточара и земљорадника", у чијој се структури и даље опажају реликти „паганских јавних култова” (Nedeljković, 1990: 226). У прилог томе сведоче народна веровања везана за овај дан, као и песме (Исто: 226-227; Karanović, 1996: бр. 107 и др.).

Како је четвртак код старих Словена био дан бога грома, Перуна (Перундан код Полапских и Балтичких Словена - в. Ivanov-Toporov, 1974: 24), с разлогом се може претпоставити да је Свети Спас преузео неке од Громовникових атрибута и функција. Томе у прилог говори и низ заштитних радњи које се на овај дан предузимају за заштиту усева од града и грома (Nedeljković, 1990: 229; Bandić, 1991: 332 и др.).

Сугестија богатог рода и плодности стоке присутна је и у краљичким песмама, ${ }^{24}$ којима се завршава пролећна, а почиње летња група празника:

${ }^{23}$ Можда је то тако јер се сетва као култни чин управљала првобитно по лунарном календару.

${ }^{24}$ Више о краљичком ритуалу и песмама у: Karadžić, 1857: 38-52; Zečević, 2008: 142171; Jokić, 2012. 
Кад краљ/ица победи настаје пролеће/лето, што потврђује вегетативну функцију обреда. Није зато необично што се он поклапа са сејањем или жетвом/првим плодовима: краљице понекад иду о Ђурђевдану и о Младом св. Николи, али најчешће о Духовима/Русна недеља/Русалије (седма недеља по Ускрсу), тако се, у последњем случају, готово поклапајући са дугодневицом. (Karanović, 1996: 278)

Слика изобиља у дому у овим песмама понекад добија митолошку стилизацију (У овога дома / добра домаћина / јелени волови, / калопер јармови, / босиљак палице, / жито као злато - Караџић, 1857: 40-41), а део грађе, у виду благослова, приказује прижељкивани, хиперболични призор обиља летине и сточног блага доброг домаћина (в. Jokić, 2012: 116-118). Призивање аграрног благослова на дом и домаћинство било је примарна функција ових песама, што учеснице обреда доводи у везу с аграрним култовима (в. Zečević, 2008: 156, 158). Bepуje се да магијском манипулацијом обредним реквизитима (пре свега барјацима) краљице штите атар и домаћинства од града (Jokić, 2012: 73), али оне могу и да призову град на кућу где им се замере (Zečević, 2008: 143).

Летњим обредним песмама припадају оне чије се извођење везује за Петровдан, одн. Ивањдан. И у овој групи песама изражено је убеђење да је празник само временска тачка око које се (али никако и на сам празнични дан) изводе радови, при чему се, неретко, календарски циклус усаодношава са животним кругом појединца:

Косиле се зелене ливаде

Сваког дана око Петровдана.

Просиле се лијепе ђевојке

Сваког дана око Митровдана. (Karanović - Pešikan-Ljuštanović, 1994: бp. 53)

Магијске радње практиковане ради заштите људи, поља и приноса од града и грома нарочито су изражене у кругу летњих празника, а понајвише „огњевитих светаца” (Св. великомученик Прокопије - 21. 7; Св. великомученица Марина - Огюена Марија - 30. 7; Св. пророк Илија - 2. 8; Св. Мироносна Марија Магдалена - Блага Марија - 4. 8; Св. великомученик Пантелејмон - Свети Пантелија - 9. 8) - дакле, за време оних празника током којих усеви доспевају за жетву (уп. Bandić, 1991: 345).

Притом се на „огњевите свеце” строго водило рачуна о томе да се „не ради око класја” (Vuković, 1985: 118). Међутим, веровања везана за ове празнике углавном остају ван корпуса летњих обредних песама, одн. реактуелизују се у оним песмама које тематизују огрешење о ове запрешне 
дане - у кругу хришћанских песама. Тако се у дијалогу Огњене Марије и Светог Пантелије светитељ зариче да ће сурово казнити преступнике: Тежаку ћу вола стријељати! / Младој снаши чедо уморити! (Krstanović, 1990: бр. 15)

Варовање ових дана магијски утиче на повољне услове и штити од града и грома. Тако је Илија Громовник апострофиран у једној песми за заустављање кише (в. Karanović, 1996: бр. 135), као светац који има моћ регулисања падавина. У традицији, ови дани представљају границе за време у које се (али никако на те дане) жању усеви. Ово аграрно знање остаје петрифицирано у стихованим пословицама:

„Свети Макивије ${ }^{25}$ - косе о чивије, а српове за репове. То значи да се до овога дана косило, а од овога дана почиње да се жање. Ово је важило за брдске крајеве, јер се жетва у низини обавља знатно раније.” (Vuković, 1985: 118)

Притом, оне немају апсолутно важење, будући да су локално распрострањене, тј. везују се за одређене крајеве, тип рељефа и климу.

Замишљени као „опасни” дани, хришћански празници земљорадничког календара представљали су поштоване (варовне) дане, а огрешење о њих доводило би до свирепе одмазде виших сила, што указује на њихова паганска исходишта. Својом семантиком они су, симболично и фактички, маркирали крај једног циклуса (Бадњи дан, Митровдан) као време краја, смрти, и(ли) почетак новог (Божић, Васкрс, Ђурђевдан) као време обнове, (поновног) рађања и васкрсења. Засновани на митској - цикличкој представи о времену, пратили су периодично слабљење и јачање сунца, везујући се за крајње тачке соларног циклуса (зимску краткодневицу - Св. Никола, Божић, пролећну равнодневицу с блиским јој празницима Младенци, Благовести, Цвети, летњу дугодневицу - Ивањдан и јесењу равнодневицу - период између Мале Госпојине и Крстовдана). Ови датуми служили су и као временски оријентир за благовремено обављање пољских радова, чије смењивање одражавају календарске обредне песме, ${ }^{26}$ као и стиховане пословице - зависно од простора на ком ове фолклорне форме егзистирају. Истовремено, они конкретизују и опредмећују став колектива

\footnotetext{
${ }^{25}$ Свети мученици Макавеји празнују се 14. августа по новом календару.

26 Најпотпунији след промена у природи, који собом повлачи и одређену врсту пољских радова, чува се у поменутој велигданској песми (уп. Бован, 1977: 70).
} 
„да онај ко ради мора своја дела чинити по реду, у одговарајуће време, јер је право доба за свако деловање унапред утврђено и прописано, па тако сви послови заједно чине годину дана" (Karanović - Pešikan-Ljuštanović, 1994: 6) - аграрни, календарски и магијски циклус вечног понављања, раста и дозревања, периодичног рађања и смрти вегетације.

\section{Dragoljub Ž. Perić \\ CALENDAR KNOWLEDGE AND THE AGRARIAN CALENDAR IN SERBIAN RITUAL FOLKSONGS}

\section{Summary}

The transition to agriculture as a main form of economic development necessitated an improvement in traditional measuring of time. Therefore, the lunar calendar was replaced by the solar one, in which periods of the year (summer and winter half-year) were determined on the basis of four key positions of the Sun - Winter Solstice, two equinoxes and Summer Solstice. These moments of the annual cycle were Christianized and associated with certain Christian saints, whose order of celebration gave order to field work as well. The songs discussed in the paper follow all segments of public life, from winter rites (the koledar procession), in which the dominant magical actions were those related to the growth of the seeds (together with the dance, koledars sing, ,jump, jump, koledo, for the wheat to grow this tall'), to the songs of spring circle, where the singers bestow agricultural blessings and perform magical acts to „close the winter” and „open the summer”, along with spring fieldwork. The life cycle of a seed starts with the plowing and the sowing and finishes with the collective harvest (moba). These songs keep vestiges of the ancient belief that man can benefit only from the work that is done right, by respecting the time for work, i.e. respecting the taboo regulations related to certain days, when work is avoided.

Key words: ritual folksongs, folklore temporology, agrarian calendar, solar calendar, myth, tradition, cyclic renewal.

\section{ЛИТЕРАТУРА}

Ajdačić, D. (2000). Zemljoradnički i hrišćanski kalendar balkanskih Slovena. Kodovi slovenskih kultura, 5, 127-130.

Bandić, D. (1991). Narodna religija Srba u 100 pojmova. Beograd: Nolit.

Bovan, V. (1977). Srpske narodne pesme sa Kosova i Metohije. Priština: Jedinstvo.

Bovan, V. (prir.) (2000). Obredne narodne pesme: studentski zapisi srpskih narodnih umotvorina na Kosovu $i$ Metohiji. Priština: Institut za srpsku kulturu, Banja Luka: Besjeda, Istok: Dom kulture „Sveti Sava”. 
C̆ajkanović, V. (1994). Rečnik srpskih narodnih verovanja o biljkama. knj. 4. Beograd: Srpska književna zadruga - Beogradski izdavačko-grafički zavod - Prosveta - Partenon M. A. M.

Đorđević, D. (1990). Narodne pesme iz leskovačke oblasti. Beograd: SANU Srpski etnografski zbornik XCV.

Elijade, M. (1986). Sveto i profano. Novi Sad: Književna zajednica Novog Sada.

Grbić, S. (1909). Srpski narodni običaji iz Sreza boljevačkog. Beograd: Srpska kraljevska akademija.

Ivanov, V. V. - Toporov, V. N. (1974). Исследования в области славянских древностей, лексические и фразеологические вопросы реконструкции текстов. Москва: Наука.

Jastrebov, I. S. (1886). Обычаи и пъсни турецкихъ Сербовъ: въ Призрђнъ, Ипекъ, Моравъ и Дибръ, С. Петербургъ.

Jovanović, V. (prir.) (1922). Srpske narodne pesme: antologija. Beograd: Geca Kon.

Jokić, J. (2012). Kraljičke pesme: ritual i poezija. Beograd: Društvo za srpski jezik i književnost Srbije.

Karanović, Z. - Pešikan-Ljuštanović, Lj. (1994). Poslovi i dani srpske pesničke tradicije. Novi Sad: Svetovi.

Karanović, Z. (prir.) (1996). Antologija srpske lirske usmene poezije. Novi Sad: Svetovi.

Karadžić, V. S. (1898). Srpske narodne pjesme: knjiga peta u kojoj su različne ženske pjesme, skupio ih V. S. Karadžić, Beograd: Državno izdanje.

Karadžić, V. S. (1857). Život i običaji naroda srpskoga. Beograd: Srpska književna zadruga.

Karadžić, V. S. (1988). Srpske narodne pjesme: knjiga prva u kojoj su različne ženske pjesme. V. Nedić. (prir.), Sabrana dela V. Karadžića. Knj. 4. Beograd: Prosveta.

Krstanović, Z. (prir.) (1990). Zlatna pjena od mora: narodne pjesme Srba u Hrvatskoj. Beograd: Rad.

Nikolić, I. (prir.) (1966). Goro le, goro zelena: antologija narodne lirike iz istočne Srbije. Zaječar: Novinska ustanova „Timok”.

Pešikan Ljuštanović, Lj. (prir.) (2012). Lirske narodne pesme. Novi Sad: IC Matice srpske.

SM (2001). Slovenska mitologija. S. M. Tolstoj i Lj. Radenković (red.). Beograd: Zepter Book World. 
Stanojević, M. (1929): M. Stanojević, Običaji i verovanja na Timoku, Beograd: Glasnik etnografskog muzeja, IV, 42-54.

Vrčević, V. (1883). Tri glavne narodne svečanosti: Božić, krsno ime i svadba, Pančevo: Naklada knjižare braće Jovanovića.

Vuković, M. (1985). Narodni običaji, verovanja i poslovice kod Srba. Beograd: b. i. Zečević, S. (2008). Srpska etnomitologija. Beograd: Službeni glasnik.

Zlatanović, M. (prir.) (1982). Lirske narodne pesme iz južne i istočne Srbije, Beograd: Narodna knjiga 1982. 